\title{
Chapter 7 \\ Accessing the Danish Labour Market: \\ On the Coexistence of Legal Barriers and Enabling Factors
}

\author{
Liv Bjerre, Michelle Pace, and Somdeep Sen
}

\subsection{Introduction}

Denmark is often considered a "first mover" when it comes to the formulation, ratification and implementation of liberal international and national migration conventions and laws. It was the first country to sign and ratify the UN Refugee Convention which was adopted in 1951. Denmark has also been resettling refugees since 1956 and officially established a refugee resettlement program in 1979 (Olwig and Paerregaard 2011: 3). In 1983 Denmark ratified the Aliens Act, which is often considered one of the most liberal immigration laws in Europe. ${ }^{1}$ The law specified that refugees ${ }^{2}$ were legally entitled to family reunification, language training, financial and residential support and a work permit (Pedersen 1999; Hedetoft 2006). To an extent, these measures reflected the existence of a "general principle of welfare community inclusion" (Mouritsen and Olsen 2013: 694; see also Soysal 1994). And, to that end, the Aliens Act was an outgrowth of Denmark's long-standing effort to "cultivate a self-image of tolerance" encapsulated in a welfare state that guarantees "high levels of public provisions (healthcare, education, unemployment benefits, old-age pensions, etc.), accessible to all citizens and residents in the country" (Pace 2018: 786).

In recent years, however, Denmark - on the basis of a political discourse that insists that refugees in particular are a burden to the welfare state and their culture incompatible with Danish values - has aspired to be a different kind of "first mover"; namely, as a pioneer of some of the most restrictive asylum policies in Europe

${ }^{1}$ This, in spite of the problematic title (i.e. Aliens Act) of the law.

${ }^{2}$ As well as non-refugee migrants.

\section{Bjerre $\cdot$ M. Pace $(\bowtie) \cdot$ S. Sen}

Department of Social Sciences and Business, Roskilde University, Roskilde, Denmark e-mail: mpace@ruc.dk 
(Delman 2016; Abend 2019; Khalid and Mortensen 2019; Westers $\varnothing 2019$; Agerhold 2016.). As we go on to demonstrate later in this chapter, the cultivation of this new image as a "bad destination" for those seeking asylum included ever-more restrictive immigration regulations, limited access to family reunification and cuts in the social and financial assistance guaranteed by the welfare state (Taylor 2015). Instinctively, one would expect that policies restricting entry into Denmark will be paired with antagonistic policies towards refugees within Denmark. To an extent, Denmark has indeed witnessed the creation of a far more hostile integration policy landscape targeting not just refugees but also economic migrants and Danish citizens with a migrant background in the aftermath of the 2015 European "refugee crisis". In this chapter we demonstrate, however, that while barriers to entering Denmark have been mirrored in some integration-related restrictive measures within Denmark, this has not been the case with regard to refugees' integration into the Danish labour market. Surprisingly perhaps, we argue that the structure and norms of the Danish labour market are such that they in fact facilitate refugees' integration in the work force and legally protect their rights. ${ }^{3}$ To be sure, this protection, often guaranteed by key labour market stakeholders, is a way of securing the rights of Danish workers who would be adversely affected by the proliferation of an unregulated labour market where refugees are compelled to work under worse legal and economic conditions. Nevertheless, and in effect, the case of refugees' integration into the Danish labour market ends up being one where, counterintuitively, legal barriers to entering Denmark coexist alongside enabling legal guarantees of refugees' rights in the Danish labour market.

This chapter begins by describing Denmark's shift in stance, both in terms of rhetoric and policy-making, from "being a first mover" with regard to progressive migration policies to pioneering some of the most restrictive and antagonistic measures in the region and globally. Subsequently, we demonstrate that Denmark's posturing externally is not entirely reflected in the manner in which refugees encounter the Danish labour market. We elaborate that refugees' rights and privileges within the Danish workforce are guaranteed by the Danish labour market model that ensures that safe and fair working conditions are guaranteed to all workers in employment.

\footnotetext{
${ }^{3}$ It is important to note that while migrants with a humanitarian residence permit or with a residence permit on the grounds of family reunification can take up any job, non-Nordic/EU/EEA migrant workers' access to Denmark is conditional upon the existing job schemes. The current job schemes aim at attracting high-skilled labour and include among others: The Fast-track Scheme, the Pay Limit Scheme, the Positive List, schemes for researchers, employed PhDs and guest researchers and Start-up Denmark (scheme for self-employment). But while, ostensibly, the main entry routes for migrant workers are reserved for high-skilled professionals, a report from the Nordic Council of Ministers from 2010 concludes that Denmark fares very poorly in comparison to the other Nordic countries in regard to attracting high skilled workers. "An immediate explanation for this may be the tightening of the regulatory framework for access to Denmark from countries which were implemented in 2002", as stated in the report (Kornø 2010).
} 


\subsection{The Proliferation of Restrictive Measures}

Claiming that Denmark, in the past, has been a front runner in the implementation of liberal migration policies is not, however, to argue that the political landscape within the country has been devoid of any criticism of the influx of foreigners. Especially with the implementation of the Aliens Act, conservative politicians considered migrants to be an invasive demographic presence that would have a detrimental impact on the economic, socio-political and cultural character of Danish society (Hvenegaard-Larsen 2002; Mouritsen and Olsen 2013; Jørgensen 2006; Nannestad 2004). This antagonistic narrative has only intensified over the years and, especially in the past decade, public intellectuals and politicians have consistently raised severe concerns regarding immigrants in general and refugees in particular becoming a burden on the Danish welfare state - not least in terms of their limited integration into the Danish labour market (The Ministry of Finance 2017). For instance, on the basis of a 2011 study conducted by the conservative Danish thinktank CEPOS that claimed that immigrants from "non-Western countries and their dependents" cost the Danish state $€ 2$ billion every year, the far-right Danish People's Party (DF) politician Pia Kjærsgaard declared that unemployed immigrants were the most significant challenge faced by the welfare state (Lehmann 2011; see also Bloch 2017). Similarly, in 2015, the Dansk Arbejdsgiverforening or the Confederation of Danish Employers' (DA) administrative director Jørn Neergaard Larsen said, "It is catastrophic that we are so bad at integrating refugees into the Danish job market. That is not acceptable for our refugees, and as a society we simply cannot afford to let this group be taken care of by public benefits" (The Local 2015; also see Andersen 2003).

Of course, any discussion of the antagonism towards migrants in the political discourse would be incomplete without recognizing the securitization of the figure of the migrant (Sen and Pace 2018; Barrett 2018, 2019; Mouritsen and Jensen 2014). In this regard, a "watershed" moment came in the aftermath of the Muhammad Cartoon Crisis and the outrage it led to among Muslim communities within and outside Denmark. When on 30th September 2005 Jyllands Posten published cartoons depicting the Prophet Muhammad (i.e. a practice considered blasphemous in Islam), the newspaper claimed that it was practicing its right to freedom of speech and encouraging a critical public discourse of Islam (Jyllands Posten 2006). Yet, for some commentators, the response to the cartoons was evidence of rampant religious intolerance and radicalism among (often, young) non-Western immigrants in Denmark (Ammitzbøll and Vidino 2007). Evidently, this narrative coincided with the post-9/11 global concerns regarding Islamic radicalism and terrorism and a 2007 survey showed that $42 \%$ of Danes were concerned about terrorism, criminality and (the lack of) integration of non-EU residents in Denmark (Avisen 2007; also see Ottesen 2017). This narrative was further encouraged by the so-called 2015 "refugee crisis" and related security concerns. Following the 2015 attack on the Danish synagogue DF politician Pia Kjærsgaard accused Danish Muslims "of living at a lower stage of civilization, with their own primitive and cruel customs" (The 
Economist 2015). In the same vein, following the wave of terror attacks in several European countries, DF's Martin Henriksen claimed in parliament that "there is a direct correlation between refugees and terrorism" (quoted in Ritzau 2016).

Expectedly, this political discourse has encouraged the implementation of stricter immigration regulations in the last decade. And, since the beginning of the "refugee crisis", Danish authorities have engaged in a concerted campaign to portray Denmark as less attractive to asylum seekers. For example, the discretionary powers of the police were expanded to handle asylum seekers (Hvidtfeldt and Schultz-Nielsen 2017: 53). The police were given greater powers to withhold people, for instance, in order to ensure his/her presence during the asylum phase and during any appeal. A new and lower integration benefit system replaced social assistance for those who have not been in Denmark for more than seven of the last eight years (Kvist 2016). Fines for irregular stay, entry and work were raised in 2015, along with fines for aiding so called "irregular immigrants" cross the border (Hvidtfeldt and Schultz-Nielsen 2017: 52). Moreover, carrier sanctions (Schengen internal) ${ }^{4}$ and border controls were introduced (Hvidtfeldt and Schultz-Nielsen 2017: 53). In February 2016 the right to family reunification for people with temporary protection status was restricted. Now it can only be availed after three years of residency, as opposed to the previous residency requirement of one year (Hvidtfeldt and Schultz-Nielsen 2017: 53, Kvist 2016). More stringent eligibility requirements for permanent residency were also introduced (Hvidtfeldt and Schultz-Nielsen 2017: 54). Moving on from these strict restrictions implemented to limit immigration to Denmark, the next section focuses on the legal guarantees of labour rights within the Danish labour market model.

\subsection{Legal Guarantees of Labour Rights}

The Danish private labour market consists of small and medium-sized enterprises (SMEs) as well as large multinational companies. The business sector is generally characterised by a high degree of individual specialisation and flexibility in terms of adapting to market changes. Denmark has a strong reputation for high quality food and design, as well as in telecommunications, IT, pharmaceuticals, electronics and biotech more recently. A majority of the population has either a vocational or a higher education. As far as the workforce is concerned, the labour market comprises more than $50 \%$ of the population - a relatively high percentage compared to other countries, partly due to the very high employment rate of women (Norrbom Vinding 2014). The overall employment rate was $78.2 \%$ in 2018 (Eurostat 2018). To be sure,

\footnotetext{
${ }^{4}$ Carrier sanctions - meaning that air carriers as well as bus, train and maritime carriers can be subject to criminal liability if they bring a foreigner without the required travel ID across external Schengen borders - have been in place since the late 1980s. What is however new is that, as of 2015, there are now carrier sanctions for bringing people across an internal Schengen border (Hvidtfeldt and Schultz-Nielsen 2017: 53).
} 
Denmark has a long history of mass emigration, primarily to the United States (Semmingsen 1972; Larsen 1982; Hatton 1995). However, its increasingly robust economy and labour market has meant that Denmark has witnessed a greater influx of migrants and has been a net-migration country since the 1960s. Today, the foreign-born population makes up $10 \%$ of the total population. Of these, $25 \%$ have Danish citizenship, and 3.9\% are born in other EU/Nordic countries. The majority of the (non-EU/Nordic) foreign-born population originates from Syria, Turkey, Iraq, Bosnia and Herzegovina, Iran, Pakistan, Afghanistan, Lebanon, Somalia and China. A smaller share of the foreign-born population (as compared to the Danish-born population) falls within the age groups $<18$ years and $60+$ years, while a greater share falls within the working age. ${ }^{5}$ Since 2014 , more than 65,000 foreigners arrived in Denmark each year, with a peak in 2015 with more than 75,000 arrivals. The 2015 peak is mirrored in the subpopulation of immigrants who are non-EU citizens. In 2015, 38,353 non-EU citizens immigrated to Denmark compared to 29,019 in 2014 and 34,564 in 2016. This peak is primarily a result of the increase in the number of asylum seekers. The success rate (recognition rate) of applications processed in Denmark has dropped in recent years. It reached a record high of $85 \%$ in 2015 , dropped to $72 \%$ in 2016 and came down to $36 \%$ in 2017 , primarily reflecting the source countries of the applicants (the percentage of Syrians and Eritreans dropping, meaning that a greater share now come from other countries, who have a smaller chance of being granted refugee status) (Bendixen 2018).

Evidently, Denmark has adopted an increasingly hardline approach to its immigration policy-making and, as we have discussed earlier, the discursive construction of migrants as a burden to the Danish welfare state seems to be the key narrative driving recent immigration policies. One would then instinctively expect such restrictive immigration policies directed towards refugees to be "paired" with equally restrictive integration policies - especially with regard to refugees' integration into the Danish labour market. Yet, we would argue, labour market integration policies largely enable refugees's integration into the Danish labour market. For one thing, their enabling nature is shaped by the particular (institutional) character of the way in which integration policies in general and labour market integration policies in particular are implemented. With its three-tier system comprising the state, the region, and the municipality, the Danish governance structure leaves it to municipalities to implement integration policy - housing for refugees, integration/introduction programs, welfare benefits and finding jobs/education. All 98 municipalities in Denmark have complete discretion and independence in interpreting, managing and adapting integration policies, which further allows them to cater for the specific needs of local communities: municipalities are thus seen as best suited to address their communities' needs especially with regards to employment, education and language skills (Jørgensen 2014). The discretionary power in regard to the implementation of the law allows for diverging strategies and measures across municipalities, which might result in different outcomes. For instance, a memo from The

\footnotetext{
${ }^{5}$ See here: https://www.sirius-project.eu/sites/default/files/attachments/WP2_D2.2.pdf
} 
Agency for International Recruitment and Integration (2017) shows significant municipal differences in the employment rate of female refugees arriving during the period 2015-2017, potentially as a consequence of differences in the administration of the integration law. These differences could also be attributed to other factors, for example, differences in the refugees' countries of origin across municipalities. Yet, despite differences in the way in which municipalities implement integration policies, a key consequence of this governance structure is that the restrictive approach undertaken with regard to Danish immigration policy does not necessarily impact the implementation of integration policies at the municipal-level, wherein the primary responsibility of municipality authorities is to enable refugees' (and non-refugee migrants') integration into the Danish labour market.

This said, the foundational character of the Danish labour market is conducive to refugees' integration into the workforce. Here we can look to the so-called September Compromise - often considered the constitution of the Danish labour market - that was signed on 5 September 1899. The agreement was seen as a national agreement for Danish industrial relations. It was signed by the Danish Employers' Confederation (DA) and the Danish Confederation of Trade Unions (LO). The intention of the agreement was to end long periods of strikes by employees and lock-outs. Considering the industrial cost of these negotiation 'tactics' the settlement was to both secure the employers' right to regulate the work environment and to establish a bargaining system that had an embargo on strikes and lockouts. Through the September Compromise employers were able to secure their right to regulate the work environment. Additionally, both parties recognized each other's right to implement work stoppages. However, work stoppages needed to be approved by three quarters of the members and sufficient notice would need to be given prior to work stoppages. The agreement resulted in a centralized bargaining system whereby negotiations would take place between the two confederations representing the employers and the unions (Jørgensen 1999). As a consequence then, in Denmark, wage and work conditions are primarily regulated by collective agreements (or individual employment contracts) and not by law. This system of labour market regulation is referred to as The Danish Labour Market Model and is characterized by the fact that "the social partners themselves determine the rules of the game on the labour market" (The Ministry of Employment 2018). The underlining assumption here is that employers and employees are organized in associations and unions that protect their interests during collective agreement negotiations. This means that pay and work conditions are agreed freely between employers and employees through the various employers' organizations and trade unions (3F 2015).

This system of labour market regulation as well as its implications for the integration of refugees is important because it is this character of the labour market that shapes the nature of their entry into the Danish labour force. For one thing, in Denmark access to the labour market is considered an important pillar for integration. Article 1 of the Integration Act explicitly stipulates that: "making newly arrived aliens self-supporting as quickly as possible through employment" is a key objective of integration efforts (Integration Act No. 1115 of 23 September 2013). To be sure, asylum seekers are not allowed to take up work during the first six months 
from their arrival, meaning that they have little chance of an everyday life outside the asylum centre. Refugees and family reunified persons, on the other hand, are obliged to take part in an integration program, with a clear focus on labour market participation (The Ministry of Immigration and Integration 2016: 51). This program, catering for refugees and their family members, consists of Danish education and employment-oriented offers in the form of guidance and upgrading, business practice, and employment with wage subsidies (The Ministry of Immigration and Integration 2018). The integration program is implemented in the municipalities and goes hand in hand with an integration contract that must be signed in order to receive an integration allowance. The integration contract must entail a description of the immigrant's employment and education goals together with a detailed description of the activities ensuring that the goals are met. Thus, the contract is tailored to each individual and specific goals and the identifiable means leading to employment must be described in the contract (The Ministry of Immigration and Integration 2019).

The Integration program is a one-year program, as the intention is to get refugees (and their family members) into employment within one year. It can, however, be extended with up to four additional years if employment is not achieved (The Ministry of Immigration and Integration 2016: 51). The guiding principle is that those that have been granted asylum must "work from day one" (The Ministry of Immigration and Integration 2016: 52). To this end, refugees and family reunified persons in the integration program are automatically regarded as "job-ready"; meaning that they should be enrolled in job training unless considered ineligible (due to health issues etc.) (The Ministry of Immigration and Integration 2016: 51).

In Denmark, the Assessment of Foreign Qualifications Act entitles all holders of foreign qualifications to an assessment through the central recognition agency (OECD 2017: 13). To this end, the Danish Agency for Higher Education (Styrelsen for Institutioner og Uddennalesest $\varnothing$ tte) is able to provide qualification assessments to authorities responsible for the integration of MRAs as well as individual MRAs free of charge. (The Ministry of Immigration and Integration 2016: 58). This service is provided for the assessment of all levels of education (The Ministry of Immigration and Integration 2016: 58), and Denmark is among the relatively few countries that grants special recognition of prior learning procedures for humanitarian migrants who do not have documentary proof of their qualification (OECD 2017: 39). Even immigrants who do not formally require recognition (i.e. because they intend to work in a non-regulated profession) are encouraged to use this offer (OECD 2017: 13).

Since the Danish labour market leaves its regulation to the social partners, focus on antidiscrimination at the national level has not been strong in Denmark (Jørgensen 2014: 18). As a result of Denmark's (lack of) anti-discrimination policies, the Migrant Integration Policy Index (MIPEX) ranks Denmark number 27 out of 38 countries in the field of antidiscrimination policies, among others because Danish anti-discrimination legislation is split into several acts (Huddleston et al. 2015). Section 70 of the Danish Constitution states that nobody can be deprived of any civil or political rights on grounds of faith or origin, but there is no general prohibition 
against discrimination in the Danish Constitution. According to Jørgensen, this lack of a general prohibition against discrimination allows the state to promote the majority culture in specific areas, for example religion (2014: 18). The consequences of this were evident back in 2000, when a trainee was turned away from the Danish department store Magasin for turning up to work wearing a headscarf. The store management claimed that the headscarf did not comply with their rules governing employee clothing. The case was instantly taken up in the courts and the high court (Østre landret) ruled that Magasin's reason had no legal foundation and therefore constituted indirect discrimination. The young woman received compensation. The high-court decision resulted in many companies having to change their employee clothing policies. Following the ruling, employees now had the right to wear a headscarf at work (Lukowski 2010). Yet, in 2005, the Danish Supreme Court ruled in the so-called "Føtex case", where a woman had been fired for refusing to take off her headscarf at work in the department store (Supreme Court of Denmark 2005). The unanimous verdict stated that the dismissal was justified and was not a case of illegal discrimination because an employer has the right to stipulate a dress code for its employees. The ruling was significant in terms of its implications for the labour market integration of immigrants wearing a headscarf or other religious symbols as it limits not only their freedom of expression but the range of potential workplaces. Further, it provided employers with a potentially "easy tool" to dismiss employees who carry religious symbols. In 2018 Danish lawmakers also passed a law that banned the burqa and niqab. Responding to the ratification of the law, Amnesty International's Europe Director Gauri van Gulik said, "If the intention of this law was to protect women's rights, it fails abjectly. Instead, the law criminalises women for their choice of clothing and in so doing flies in the face of those freedoms Denmark purports to uphold". While only a "few Muslim women in Denmark wear full-face veils," the law would expectedly affect their ability to integrate into the Danish labour market (The Guardian 2018).

For undocumented migrants residing in Denmark without residency documentation is extremely difficult. There is a general societal belief that undocumented immigration challenges the Danish universalist welfare tradition as undocumented immigrants do not enjoy any protection, have no right to social benefits, have extremely limited access to health care, have no political rights and do not pay taxes (Tranæs and Jensen 2014: 7). In Denmark, the personal ID number (CPR) is the gateway to basically everything, from healthcare to opening a bank account, getting a Danish phone number, registering at a Danish language school or even getting a gym membership (Bahgat 2018). In this way, the Danish system can be said to work in favour of legal stay and against undocumented migration. At the same time, however, the total lack of access to Danish society without proper documents puts the undocumented population in Denmark under pressure and makes them vulnerable to exploitation and abuse as they become dependent on employers and/or alternative sources of income and assistance in a "shadow" society (Tranæs and Jensen 2014: 
74). This precarity of undocumented life in Denmark may then explain the relatively few (reported) undocumented workers in the country. ${ }^{6}$

Overall, therefore when we look at the balance sheet of Denmark's legal barriers and enabling factors to in particular labour market integration for MRAs we have quite a mixed picture. However, we sustain that while "barriers" exist in terms of entering Denmark, the Danish labour market model facilitates refugees' integration and legally ensures the protection of their labour rights. Therefore, the Danish case study shows that legal barriers (to entering the labour market) coexist alongside enabling factors (legal guarantees) of refugees' rights.

\subsection{Conclusion}

Following a general election in June 2019, Denmark now has a new government made up of left-wing parties (that won an overall majority in said election). Prior to the election, Social Democrat leader Mette Frederiksen (now Denmark's prime minister) had stressed that she would continue the "broad" approach of the previous government on refugees as well as immigration, including the so-called 'paradigm shift' - referring to the then government's policy of returning refugees to their source countries once it is deemed safe to do so, rather than integrate them in Denmark: "We are still focused on repatriation and temporary asylum. When you are a refugee and come to Denmark, you can be granted our protection. But when there's peace, you must go home" (Wenane 2019). The other three parties - the Social Liberals, the Socialist People's Party and the Red-Green Alliance - had all called for a more lenient approach to refugees. The coalition agreement reflects this, with pledges to improve conditions for families of rejected asylum seekers and to move families with children from Sjælsmark deportation centre to a more humane facility. ${ }^{7}$ Other aspects of the agreement include opening the doors for more high-skilled foreign workers.

The new Social Democratic government and its support parties also announced that refugees who lose their residence permit if conditions in their home country improve will be allowed to stay if they had a job for a minimum of 2 years and still have it. According to refugees.dk this may already be relevant for some of the 900 Somali refugees who lost their permits during the last year, and for many Syrians in the future (Bendixen 2019). The Red/Green Alliance (Enhedslisten) added that all refugees will get the same right to free education - which the 4500 Syrians with a

\footnotetext{
${ }^{6}$ The Danish Police reported only 190 cases of undocumented workers in the third quarter in 2019 (Politi 2019).

${ }^{7}$ A study conducted by the Danish Red Cross expressed severe concern regarding the psychological welfare of children at the deportation centre and reported that a large proportion of the children displayed significant levels of mental health issues (Red Cross 2019; Nilsson and Hergel 2019; The Local 2019).
} 
temporary protection 7(3)-status ${ }^{8}$ do not have today. Another announcement was made in regard to refugee families with less than 9 years stay in Denmark, receiving integration benefit: These families will now not be subject to the previously announced reduction in benefits (which was part of the annual finance act for 2019), and they will be receiving a special child benefit given temporarily to the poorest families with children while a commission will be looking into poverty benefits in general.

This new government is thus trying to change the course on immigration policy in a more humanitarian direction. However, we are cautiously optimistic and sustain that since historically restrictive measures have been imposed while at the same time embedded in a climate that emphasizes and guarantees workers' (social and legal) rights, we cannot be overly sure that these more recent moves go beyond symbolic politics. As we have highlighted throughout this chapter, Denmark is a clear case of how a first mover of a positive kind in terms of immigration laws and policies quickly shifted to a first mover of a highly negative and often symbolic kind - albeit with real impacts for MRAs. However, we conclude that, in spite of the highly securitized and "burden" narratives that have sought to portray MRAs in a negative light, Denmark remains overall a success story for MRAs' integration into the labour market. As 51-year-old Ghais Sangari, formerly an Afghan war refugee, but now a successful businessman with a Danish passport, puts it: "Many immigrants speak negatively about Denmark. I would rather talk about all the positive things about Danish society. I always say to my children: 'If you work hard, read and get good grades, you can do whatever you want in Denmark.' It is the most important thing" (own translation from Danish, Euroman 2019: 91).

\section{References}

3F. (2015, November 11). The Danish Labour Market Model. 3F. https://tema.3f.dk/byg-job/english/the-danish-labour-market-model. Accessed 14 July 2019.

Abend, L. (2019, January 16). An island for 'unwanted' migrants is Denmark's latest aggressive ant-immigrant policy. Time Magazine. https://time.com/5504331/denmark-migrants-lindholmisland/. Accessed 12 July 2019.

Agerhold, H. (2016, July 1). Denmark uses controversial 'jewelry law' to seize assets from refugees for first time. The Independent. https://www.independent.co.uk/news/world/europe/ denmark-jewellery-law-migrants-refugees-asylum-seekers-unhcr-united-nations-a7113056. html. Accessed 12 July 2019.

Ammitzbøll, P., \& Vidino, L. (2007). After the Danish cartoon controversy. Middle East Quarterly, 14(1), 3-11.

Andersen, J. G. (2003). The Danish People's Party and new cleavages in Danish politics (working paper). Aalborg: Center for Comparative Welfare Studies, Aalborg University.

\footnotetext{
${ }^{8}$ For more information see here: http://refugees.dk/en/facts/legislation-and-definitions/ more-about-art-7-3-temporary-protection-status/
} 
Avisen.dk. (2007, May 24). Danskerne er bange for terror og indvandrer [Danes are afraid of terrorism and immigrants]. https://www.avisen.dk/danskerne-er-bange-for-terror-ogindvandrere_70177.aspx. Accessed 12 July 2019.

Bahgat, F. (2018, March 15). Is life in Denmark impossible without a personal registration number? The Local. https://www.thelocal.dk/20180315/is-life-in-denmark-impossible-without-apersonal-registration-number. Accessed 16 July 2019.

Barrett, M. (2018, December 1). Denmark to banish foreign convicted criminals to deserted island. The Local. https://www.thelocal.dk/20181201/denmark-to-banish-foreign-convictedcriminals-to-deserted-island. Accessed 12 July 2019.

Barrett, M. (2019, January 24). Three years after Denmark's infamous 'jewellery law' hit world headlines, not a single piece has been confiscated. The Local. https://www.thelocal. $\mathrm{dk} / 20190124 /$ three-years-after-denmarks-infamous-jewellery-law-hit-world-headlines-not-asingle-piece-has-been-confiscated. Accessed 12 July 2019.

Bendixen, M. C. (2018, January 29). What are the chances of being granted asylum? Refugees Welcome. $\mathrm{http} / / /$ refugees.dk/en/facts/numbers-and-statistics/what-are-the-chances-of-beinggranted-asylum/. Accessed 12 July 2019.

Bendixen, M. C. (2019, June 30). Good news for Syrian refugees in Denmark. Refugees Welcome. http://refugees.dk/en/news/2019/june/good-news-for-syrian-refugees-in-denmark/. Accessed 12 July 2019.

Bloch, C. (2017, April 10). Inger Støjberg om flygtninge: "Vi har pakket dem ind i velfærd. Og vi har lullet dem i søvn, så hænderne lige så stille er sunket ned i skødet" [Inger Støjberg on refugees: "We have wrapped them [immigrants] in welfare. Lulled them to sleep and their hands have laid still on their laps"]. Berlingske. https://www.berlingske.dk/politik/inger-stoejbergom-flygtninge-vi-har-pakket-dem-ind-i-velfaerd.-og-vi-har-lullet. Accessed 14 July 2019.

Delman, E. (2016, January 27). How not to welcome refugees. Atlantic. https://www.theatlantic. com/international/archive/2016/01/denmark-refugees-immigration-law/431520/. Accessed 12 July 2019.

Euroman. 2019. Gennembruddet fra ghettoen [The breakthrough from the ghetto]. April Edition, pp. 72-93.

Hatton, T. J. (1995). A model of Scandinavian emigration. European Economic Review, 39(3-4), $557-564$.

Hedetoft, U. (2006). Denmark: Integrating immigrants into a homogenous welfare state. Migration Policy Institute. https://www.migrationpolicy.org/article/denmark-integrating-immigrantshomogeneous-welfare-state. Accessed 12 July 2019.

Huddleston, T., Bilgili, Ö., Joki, A.-L., \& Vankova, Z. (2015). Migrant integration policy index 2015. CIDOB and MPG: Barcelona/Brussels.

Hvenegaard-Lassen, K. (2002). På lige fod, samfundet, ligheden og folketingets debatter om udlandingepolitik 1973-2000 [On equal footing, the society, equality and parliamentary debates on foreign policy between 1973-2000] (PhD Dissertation). Copenhagen: University of Copenhagen.

Hvidtfeldt, C., \& Schultz-Nielsen, M. L. (2017). Flygtninge og asylansøgere i Danmark 1992-2016 [Refugees and asylum seekers in Denmark 1992-2016]. Copenhagen: Rockwool Foundation.

Jørgensen, C. (1999, August 27). September Compromise marks 100th anniversary. Eurofund. https://www.eurofound.europa.eu/observatories/eurwork/articles/industrial-relations/ september-compromise-marks-100th-anniversary. Accessed 12 July 2019.

Jørgensen, L. (2006). Hvad sagde vi!...om "De Andre". Den udlandingepolitiske debat $i$ Folketinget 1961-1999 [What did we say... about "the others". The foreign policy debate in the parliament 1961-1999]. PhD dissertation. Roskilde: Roskilde University.

Jørgensen, M. B. (2014). Decentralising immigrant integration. In Denmark's mainstreaming initiatives in employment, education, and social affairs. Brussels: Migration Policy Institute Europe.

Jyllands, P. (2006, September 30). Muhammed-krisen - sådan gik det til [The Muhammad Crisis Here is how it happened]. https://jyllands-posten.dk/indland/article4302432.ece/. Accessed 14 July 2019. 
Khalid, F., \& Mortensen, N. H. (2019, June 4). How anti-immigrant sentiment infected Denmark's politics. New Statesman. https://www.newstatesman.com/world/europe/2019/06/how-antiimmigrant-sentiment-infected-denmark-s-politics. Accessed 12 July 2019.

Korn $\varnothing$, H. R. (2010, June 10). Denmark loses the battle for high-skilled immigrants. Danish Green Card Association. https://danishgreencard.wordpress.com/2010/06/10/denmark-loses-thebattle-for-high-skilled-immigrants/. Accessed 12 July 2019.

Kvist, J. (2016). Recent Danish migration and integration policies. European Social Policy Network Flash Report - 2016/14. https://ec.europa.eu/social/BlobServlet?docId=15320\&lan gId=en. Accessed 12 July 2019.

Larsen, U. M. (1982). A quantitative study of emigration from Denmark to the United States, 1870-1913. Scandinavian Economic History Review, 30(2), 101-128.

Lehmann, C. (2011, March 7). Arbejdslфse indvandrere er den største velfardsudfordring [Unemployed immigrants are the biggest welfare challenge]. Information. https://www.information.dk/indland/2011/03/arbejdsloese-indvandrere-stoerste-velfaerdsudfordring, Accessed 14 July 2019.

Lukowski, S. (2010). Headscarves in Danish workplaces. Kvinfo, April 14. https://kvinfo.dk/ headscarves-in-danish-workplaces/?lang=en. Accessed 16 July 2019.

Mouritsen, P., \& Jensen, C. H. (2014). Integration policies in Denmark (INTERACT Research Report 2014/06). http://cadmus.eui.eu/bitstream/handle/1814/32020/INTERACTRR-2014_06.pdf?sequence=1. Accessed 14 July 2019.

Mouritsen, P., \& Olsen, T. V. (2013). Denmark between liberalism and nationalism. Ethnic and Racial Studies, 36(4), 691-710.

Nannestad, P. (2004). Immigration as a challenge to the Danish welfare state. European Journal of Political Economy, 20(3), 755-767.

Nilsson, K., \& Hergel, O. (2019, April 5). Røde Kors om mistrivsel på Sjælsmark: 6 ud af 10 unders $\varnothing$ gte børn kunne få en psykiatrisk diagnose (Red Cross on dissatisfaction at Sjælsmark: 6 out of 10 children examined could receive a psychiatric diagnosis). Politiken. https://politiken. dk/indland/art7127117/6-ud-af-10-unders\%C3\%B8gte-b\%C3\%B8rn-kunne-f\%C3\%A5-enpsykiatrisk-diagnose. Accessed 12 July 2019.

Norrbom Vinding. (2014). Setting up in Denmark. In A brief introduction to labour and employment law in Denmark. Copenhagen: Norrbom Vinding.

OECD. (2017). Making integration work: Assessment and recognition of foreign qualifications. Paris: OECD Publishing.

Olwig, K. F., \& Pærregaard, K. (2011). Introduction: Strangers in the nation. In K. F. Olwig \& K. Pærregaard (Eds.), The question of integration: Immigration, exclusion and the Danish welfare state (pp. 1-29). Newcastle upon Tyne: Cambridge Scholars Publishing.

Ottesen, K. (2017, March 15). To ud af tre danskere vil have farre muslimske indvandrere til Danmark [Two out of three Danes want fewer Muslim immigrants in Denmark]. DR. https:// www.dr.dk/ligetil/indland/ud-af-tre-danskere-vil-have-faerre-muslimske-indvandrere-tildanmark. Accessed 14 July 2019.

Pace, M. (2018). Overcoming bordering practices through the arts: The case of young Syrian refugees and their Danish counterparts in Denmark. Geopolitics, 23(4), 781-802.

Pedersen, S. (1999). Indvandringen til Danmark [Immigration to Denmark]. In D. Coleman \& E. Wadensjo (Eds.), Indvandringen til Danmark (pp. 1-15). Copenhagen: Spektrum.

Politi. (2019, October). Ulovligt arbejde efter udlændingelovens $§ 59$, stk. 3 og 5. Copenhagen: Politi. https://politi.dk/-/media/mediefiler/landsdaekkende-dokumenter/statistikker/ulovligtarbejde/2019-ulovligtarbejde3kvartal.pdf?la=da\&hash=CF4FA56098C602BD088224A51 DB10BE6691681A2. Accessed 26 Jan 2021.

Red Cross. (2019). Trivsel hos børn på udrejsecenter Sjalsmark: En psykologisk unders $\phi g e l s e$. Copenhagen: Red Cross. https://www.rodekors.dk/sites/rodekors.dk/files/2019-04/2019.03_ Sjælsmark_V09_Final_1.pdf. Accessed 8 Nov 2019.

Ritzau. (2016, December 20). DF: Der er direkte sammenhæng mellem flygtninge og terror [DF: There is a direct connection between refugees and terror]. Fyens.dk. https://www.fyens.dk/ 
indland/DF-Der-er-direkte-sammenhaeng-mellem-flygtninge-og-terror/artikel/3108352. Accessed 14 July 2019.

Semmingsen, I. (1972). Emigration from Scandinavia. Scandinavian Economic History Review, 20(1), 45-60.

Sen, S., \& Pace, M. (2018). The young and exiled: An introduction. In M. Pace \& S. Sen (Eds.), Syrian refugee children in the Middle East and Europe: Integrating the young and exiled (pp. 1-7). Oxon: Routledge.

Soysal, Y. N. (1994). Limits of citizenship: Migrants and postnational membership in Europe. Chicago: Chicago University Press.

Supreme Court of Denmark. (2005, January 21). Fotex Case (no. U.2005.1265.H). Religare. http:// religaredatabase.cnrs.fr/spip.php?article116. Accessed 16 July 2019.

Taylor, A. (2015, September 7). Denmark puts ad in Lebanese newspapers: Dear refugees, don't come here. Washington Post. https://www.washingtonpost.com/news/worldviews/ $\mathrm{wp} / 2015 / 09 / 07 /$ denmark-places-an-advertisement-in-lebanese-newspapers-dear-refugeesdont-come-here/?utm_term=.2592cda67f5d. Accessed 12 July 2019.

The Agency for International Recruitment and Integration. (2017). Notat vedr. kommunale forskelle $i$ integrationsindsats [Memo on municipal differences in integration efforts]. Copenhagen: The Agency for International Recruitment and Integration.

The Economist. (2015, February 17). Denmark's "failed" multiculturalism. https://www.economist.com/the-economist-explains/2015/02/17/denmarks-failed-multiculturalism. Accessed 14 July 2019.

The Guardian. (2018, May 31). Denmark passes law banning burqa and niqab. https://www.theguardian.com/world/2018/may/31/denmark-passes-law-banning-burqa-and-niqab. Accessed 8 Nov 2019.

The Local. (2015, March 9). Denmark's refugee integration has "failed". https://www.thelocal. dk/20150309/denmarks-refugee-integration-efforts-have-failed. Accessed 12 July 2019.

The Local. (2019, April 5). Over half of children at Danish refugee centre have symptoms of mental health problems: Red Cross. https://www.thelocal.dk/20190405/over-half-of-childrenat-danish-refugee-expulsion-centre-have-symptoms-of-mental-health-problems-red-cross. Accessed 12 July 2019.

The Ministry of Employment. (2018). The Danish Labour Market. The Ministry of Employment. https://bm.dk/the-ministry-of-employment/the-danish-labour-market/. Accessed 14 July 2019.

The Ministry of Finance. (2017). Økonomisk analyse: Indvandreres nettobidrag til de offentlige finanser [Economic analysis: Immigrants' net contribution to public finances]. https://www. fm.dk/oekonomi-og-tal/oekonomisk-analyse/2017/indvandreres-nettobidrag-til-offentligefinanser. Accessed 14 July 2019.

The Ministry of Immigration and Integration. (2016). International migration - Denmark. In Report to OECD. Copenhagen: The Ministry of Immigration and Integration.

The Ministry of Immigration and Integration. (2018, July 4). Integrationsprogrammet [The Integration Programme]. The Ministry of Immigration and Integration. http://uim.dk/arbejdsomrader/Integration/integrationsprogrammet. Accessed 14 July 2019.

The Ministry of Immigration and Integration. (2019, July 8). Integrationskontrakt og integrationserklaring [Integration contract and Declaration on integration]. http://uim.dk/arbejdsomrader/ Integration/integrationskontrakt-og-integrationserklaering. Accessed 16 July 2019.

Tranæs, T., \& Jensen, B. (2014). Den illegale indvandring til Europa - og til Danmark. Årsagen, omfang og betydning [The illegal immigration to Europe - And to Denmark. Causes, extent and importance]. Copenhagen: Rockwool Fondens Forskningsenhed and Gyldendal.

Wenane, C. (2019, June 26). Mette finally made it: Denmark to get a new Prime Minister. http:// cphpost.dk/news/mette-made-it-denmark-has-a-new-prime-minister.html. Accessed 12 July 2019.

Westers $\varnothing$, R. S. (2019, February 21). Nu er paradigmeskiltet vedtaget i Folketinget [The Paradigm Shift has now been adopted by the parliament]. TV2. http://nyheder.tv2.dk/politik/2019-02-21nu-er-paradigmeskiftet-vedtaget-i-folketinget. Accessed 12 July 2019. 
Open Access This chapter is licensed under the terms of the Creative Commons Attribution 4.0 International License (http://creativecommons.org/licenses/by/4.0/), which permits use, sharing, adaptation, distribution and reproduction in any medium or format, as long as you give appropriate credit to the original author(s) and the source, provide a link to the Creative Commons license and indicate if changes were made.

The images or other third party material in this chapter are included in the chapter's Creative Commons license, unless indicated otherwise in a credit line to the material. If material is not included in the chapter's Creative Commons license and your intended use is not permitted by statutory regulation or exceeds the permitted use, you will need to obtain permission directly from the copyright holder. 